\title{
Differences in Medical Marijuana Card Registration by Geographic Regions in California
}

\author{
Sean Patrick Nordt ${ }^{1}$, Lisa E. Vivero ${ }^{2}$, and Daniel Joseph ${ }^{1}$ \\ ${ }^{1}$ Department of Emergency Medicine, Los Angeles, California \\ ${ }^{2}$ Drug Information Specialist, Irvine, California
}

\begin{abstract}
California was the first state to legalize marijuana for medical purposes. Individuals are issued identification card for medical marijuana use for patients with chronic medical conditions if directed by a physician. Surveys have suggested there are regional differences between northern California residents, particularly the Bay Area, and southern California residents with respect to medical marijuana use and legalization. The purpose of this paper is to discuss the California Department of Public Health statistics regarding medical marijuana card registrations over various geographic areas of California. The California Department of Public Health Medical Marijuana Card Registration database reflects this with more individuals in the Bay Area registered compared to those in the ten southernmost counties of California. The reasons for this are unclear but could fall along political party lines as more registered Democrats support medical marijuana legalization compared to registered Republicans. The benefits of medical marijuana and potential adverse medical and socioeconomic effects have not been fully elucidated. Conclusion: There is a need for further study of the potential benefits for medical marijuana use and the reasons for apparent regional different beliefs of medical marijuana use and medical marijuana card registration.
\end{abstract}

(C) 2016 Californian Journal of Health Promotion. All rights reserved.

Keywords: Medical marijuana; cannabis; THC; cannabidiol

\section{Introduction}

Marijuana, Cannabis sativa, has been cultivated and utilized for thousands of years for recreational, spiritual, and medicinal purposes. There are several compounds in Cannabis sativa, for example, $\Delta$ 9-tetrahydrocannabinol (THC), and cannabidiol. However, THC is the most commonly cited active compound (Maule, 2015; Watson, Benson \& Joy, 2000; Reinarman, Nunberg, Lanthier, \& Heddleston, 2011). There is conflicting data about the medical benefits of marijuana (Reinarman, Nunberg, Lanthier, \& Heddleston, 2011). Although the majority of studies focus on THC there are data identifying medicinal benefits of cannabidiol to prevent seizures (Reinarman, Nunberg, Lanthier, \& Heddleston, 2011). Furthermore, cannabidiol does not have potent psychotropic properties of THC. (Szaflarski \& Bebin, 2014). The two most common routes of administration of medical marijuana is smoking and ingesting foods containing THC and/or cannabidiol (Watson, Benson \& Joy, 2000; Maccoun, \& Mello, 2015).

\section{Medical Marijuana Cards}

Medical marijuana, as we now know it, came to the forefront in the early 1990s. California was the first state to legalize medical marijuana in 1996 (Ryan-Ibarra, Induni, \& Ewing, 2014). However, medical marijuana became legal to prescribe and use only in 2003, when the Medical Marijuana Protection Act was signed into California law, which established an identification card system for medical marijuana use. These medical marijuana cards were first issued in 2004 for patients with chronic illnesses if directed by a physician (Ryan-Ibarra, Induni, \& Ewing, 2014). Currently, 23 states in the United States have legalized marijuana for medical purposes. Four states; Alaska, Colorado, Oregon, Washington and the District of Columbia have legalized marijuana for recreational use (Maule, 2015). 


\section{State versus Federal Legislation}

This legalization is at odds with the federal classification of marijuana as a Class I controlled substance with no medicinal benefits (USDOJ, 2009). However, in October 2009 U.S. Deputy Attorney General David W. Ogden issued a memo to address these competing legislations: "As a general matter, pursuit of these priorities should not focus federal resources in your States on individuals whose actions are in clear and unambiguous compliance with existing state laws providing for the medical use of marijuana. For example, prosecution of individuals with cancer or other serious illnesses who use marijuana as part of a recommended treatment regimen consistent with applicable state law, or those caregivers in clear and unambiguous compliance with existing state law who provide such individuals with marijuana is unlikely to be an efficient use of limited federal resources (USDOJ, 2009).”

\section{Medical Marijuana Use in California}

It is estimated that there are over 200,000 medical marijuana users in California (Reinarman, Nunberg, Lanthier, \& Heddleston, 2011). In California, medical marijuana is sold from "dispensaries." In California a "medical marijuana dispensary" is defined as: as any facility or location where medical marijuana is grown, made available to and/or distributed to, two or more of the following: primary caregivers, qualified patients, or individuals with identification cards (MMD, 2016). The exact number of dispensaries in California is unknown, but was estimated to be well over 1,000 in 2009 (Warner, 2009). Regulation of dispensaries has been challenging and the City of Los Angeles has closed over 500 dispensaries for various infractions including operating too close to public parks, schools and other facilities (Reyes \& Saillant, 2015).

The medical reasons for marijuana use are wide and varied including: relief from insomnia, anxiety, muscle spasms, seizures, nausea and vomiting, depression, involuntary movements, and glaucoma, to improve appetite and mental focus (Nunberg, Kilmer, Pacula, \& Burgdorf, 2011; Reinarman, Nunberg, Lanthier, \& Heddleston, 2011; Watson, Benson \& Joy,
2000). Interestingly, over half the patients report using medical marijuana as a substitute for prescription medication rather than as adjuvant agent (Reinarman, Nunberg, Lanthier, \& Heddleston, 2011).

California not only has diverse geographic regions (e.g., urban, rural, and suburban), but also diverse ethnic, religious and political groups. A telephone survey of 7,525 randomly selected adults in California found that five percent of the population sampled reported ever using marijuana for medical purposes. These authors found similar prevalence rates of medical marijuana use in northern California, southern California and the Bay Area, 6\%, 4\% and 4\%, respectively (Ryan-Ibarra, Induni, \& Ewing, 2014). However, a newspaper poll found a majority of Bay Area residents, 55\%, favored the legalization of marijuana compared to only $41 \%$ of southern California residents (Mozingo, 2012).

A study identified the locations of medical marijuana dispensaries in California being predominantly found in lower income areas and unincorporated areas, with close proximity to establishments selling alcoholic beverages (Morrison, Gruenewald, Freisthler, Ponicki, \& Remer, 2014). The authors theorized that the communities in such areas lack the resources to resist the establishment of dispensaries, compared to communities located in higher income and incorporated areas. Interestingly, another study showed $50.9 \%$ of their survey participants had at least some college or were college graduates; $64.8 \%$ of the respondents were employed and $73.4 \%$ had health insurance (Reinarman, Nunberg, Lanthier, \& Heddleston, 2011) . This seems to offer that MMIC holders travel to lower income areas to obtain medical marijuana from dispensaries whilst themselves being more educated and with higher incomes. This could reflect less access to physicians in lower income groups to approve MMIC.

We queried the publicly available California Department of Public Health's Medical Marijuana Program (MMP) registry database (CDPH, 2014). This database was specifically established to create a repository of State- 
authorized medical marijuana identification card (MMIC) issuances. The CDPH MMP was specifically established to create a Stateauthorized medical marijuana identification card, along with a registry database for verification of qualified patients and their primary caregivers. Participation by patients and primary caregivers in this identification card program is voluntary. The MMP Web-based registry allows law enforcement and the public to verify the validity of a qualified patient or primary caregiver's MMIC as authorization to possess, grow, transport, and/or use medical marijuana within California (CDPH, 2015).

The CDPH MMP lists MMIC registration by fiscal year and county only, however, does not group together in geographic regions. We evaluated two representative years, 2005 the year following MMIC implementation, and 2012, eight years after implementation and grouped by geographic regions. In the fiscal year 2005 there was a large discrepancy between geographic regions of medical marijuana card registration. For northern California, defined as the 48 northernmost counties, there were 9.3 MMIC per 100,000 residents compared to 2 MMIC per 100,000 for the 10 southernmost counties. There was less disagreement in fiscal year 2012, where northern California had 15.4 MMIC per 100,000 compared to 13.1 MMIC per 100,000 for southern California. However, selecting out the 8 Bay Area counties shows a larger penetrance of MMIC registration, 40.4 per 100,000 and 30.2 per 100,000 in fiscal years 2005 and 2012, respectively (CDPH, 2014).

\section{Potential Reasons for Geographic Differences in Medicinal Marijuana Use}

The reasons for geographic differences are unclear but possibly originate from different regional feelings and beliefs regarding marijuana use for medical purposes. This could also follow along political party lines, as the Bay Area has the largest amount of registered Democratic voters in California compared to southern California, which has a more even distribution of both Democratic and Republican registered voters (PPIC, 2014). Democratic voters in general support the legalization of marijuana compared to Republican voters (Mozingo,
2012). However, there are other potential differences for the discrepancies seen in the geographic areas. Finally, participation in the MMP database is voluntary and higher numbers reflected in our data could represent increased compliance with registering in certain geographic regions compared to others.

There are several social and cultural concerns with the legalization of marijuana for medical purposes in California. In one study, several patients who utilize medical marijuana report being stigmatized as abusers or "stoners" by friends and family rather than being accepted as using to treat a medical condition (Satterlund, Lee, \& Moore, 2015). In addition, these patients report not telling their regular physicians of medicinal marijuana use and seeking prescriptions from other physicians (Satterlund, Lee, \& Moore, 2015). This is concerning as patients may manifest clinical effects or adverse effects from medical marijuana that may be attributed to a potential disease state by their physicians if they are unaware of medical marijuana use.

\section{Conclusion}

As more states legalize marijuana for medical use there continues to be a need for wellcontrolled randomized double-blind studies to accurately assess true medical benefits. A study showed cannabis-involved driving had increased in California since 2007 in randomly selected drivers and were more likely to be MMIC holders (Johnson, Kelley-Baker, Voas, \& Lacey, 2012). Driving under the influence of THC has been shown to impair ability to drive safely (O'Kane, Tutt, \& Bauer, 2002). Therefore, there is a need to continue to study this concerning trend.

Our data suggests there may be major social and political ramifications of the variation we identified between northern California and southern California. This raises the question: Do individuals who support both the use and legalization of medical marijuana relocate to areas where there is higher use and support of medical marijuana, for example, the Bay Area? This variation could have larger political 
repercussions, with an imbalance or preponderance of one political party over another in various geographic regions of California. Federal legislation on medical marijuana and statewide dispensary regulations may obviate the current local differences in medical marijuana use and regulation.

Furthermore, as stated in the Institute of Medicine study, smoking marijuana is an "ineffective delivery device," meaning there is wide variation of dose delivered by smoking. The Institute of Medicine also cautions that smoking marijuana may result in harmful side effects from smoke (Watson, Benson \& Joy, 2000). In addition, marijuana edibles have varying concentrations of THC and rate of absorption from the gastrointestinal tract (Maccoun, \& Mello, 2015). As such, the potential beneficial compounds in marijuana medical applications should be identified and isolated to allow for more precise dosing and administration through controlled trials and the rigors of the peer-review process to further elucidate the role of medical marijuana in the treatment of patients.

\section{References}

California Department of Public Health. California Medical Marijuana Identification Card Data by County and Fiscal Year. (2014, June 3). Retrieved September 1, 2014, from http://www.cdph.ca.gov/programs/MMP/Documents/MMP County Card Count FY 13-14 May.pdf

California Department of Public Health. Medical Marijuana Program. (2015, November 20). Retrieved February 05, 2016, from http://www.cdph.ca.gov/programs/MMP/Pages/default.aspx

Johnson, M., Kelley-Baker, T., Voas, R., \& Lacey, J. (2012). The prevalence of cannabis-involved driving in California. Drug and Alcohol Dependence, 123, 105-109.

Maccoun, R., \& Mello, M. (2015). Half-Baked - The Retail Promotion of Marijuana Edibles. New England Journal of Medicine N Engl J Med, 372(11), 989-991.

Maule, W.J. (2015). Medical uses of marijuana (Cannabis sativa): fact or fallacy? British Journal of Biomedical Science, 72, 85-91.

Medical marijuana dispecnsaries. Chapter 5-28. Retrieved January 26, 2016, from http://www.codepublishing.com/CA/Emeryville/html/Emeryville05/Emeryville0528.html

Morrison, C., Gruenewald, P., Freisthler, B., Ponicki, W., \& Remer, L. (2014). The economic geography of medical cannabis dispensaries in California. International Journal of Drug Policy, 25(3), 508515.

Mozingo, J. (2012, May 31). Most California voters don't support legalizing pot, poll finds. Retrieved November 25, 2015, from http://articles.latimes.com/2012/may/31/local/la-me-0531-pot-poll20120531

Nunberg, H., Kilmer, B., Pacula, R., \& Burgdorf, J. (2011). An Analysis of Applicants Presenting to a Medical Marijuana Specialty Practice in California. Journal of Drug Policy Analysis, 4(1), 1-14.

O'Kane, C., Tutt, D., \& Bauer, L. (2002). Cannabis and driving: A new perspective. Emerg Med Australas Emergency Medicine Australasia, 14(3), 296-303.

Public Policy Institute of California. California Voter and Party Profiles. (2014, August 1). Retrieved February 23, 2015, from http://www.ppic.org/main/publication_show.asp?i=526

Reinarman, C., Nunberg, H., Lanthier, F., \& Heddleston, T. (2011). Who Are Medical Marijuana Patients? Population Characteristics from Nine California Assessment Clinics. Journal of Psychoactive Drugs, 43(2), 128-135.

Reyes, E., \& Saillant, C. (2015, April 9). L.A. credits its crackdown with shutting more than 500 pot shops. Retrieved November 25, 2015, from http://www.latimes.com/local/cityhall/la-me-0409pot-shops-20150409-story.html

Ryan-Ibarra, S., Induni, M., \& Ewing, D. (2014). Prevalence of medical marijuana use in California, 2012. Drug and Alcohol Review Drug Alcohol Rev, 141-146. 
Satterlund, T., Lee, J., \& Moore, R. (2015). Stigma among California’s Medical Marijuana Patients. Journal of Psychoactive Drugs, 47(1), 10-17.

Szaflarski, J., \& Bebin, E. (2014). Cannabis, cannabidiol, and epilepsy — From receptors to clinical response. Epilepsy \& Behavior, 41, 277-282.

United States Department of Justice. Memorandum for Selected United State Attorneys on Investigations and Prosecutions in States Authorizing the Medical Use of Marijuana. (2009, October 19). Retrieved November 25, 2015, from http://www.justice.gov/opa/blog/memorandum-selectedunited-state-attorneys-investigations-and-prosecutions-states

Warner, B. (2009, December 3). How does your pot grow? Retrieved November 25, 2015, from http://www.pasadenaweekly.com/cms/story/detail/how_does_your_pot_grow/8070/

Watson, S.J., Benson, J.A., \& Joy, J.E., (2000). Marijuana and Medicine: Assessing the Science Base: A Summary of the 1999 Institute of Medicine Report. Archives of General Psychiatry, 57, 547-552.

Author Information

*Sean Patrick Nordt, M.D., Pharm.D.

USC Keck School of Medicine, Department of Emergency Medicine, 1200 North State Street, GH 1011, Los Angeles, California 90033

Email:spnordt@hotmail.com

* corresponding author 